Article

\title{
Sustainability Indicators for the Manufacturing and Use of a Fuel Cell Prototype and Hydrogen Storage for Portable Uses
}

\author{
Daniel Garraín*(D), Santacruz Banacloche, Paloma Ferreira-Aparicio (D), Antonio Martínez-Chaparro ${ }^{D}$ \\ and Yolanda Lechón (D)
}

check for updates

Citation: Garraín, D.; Banacloche, S.; Ferreira-Aparicio, P.;

Martínez-Chaparro, A.; Lechón, Y.

Sustainability Indicators for the

Manufacturing and Use of a Fuel Cell Prototype and Hydrogen Storage for Portable Uses. Energies 2021, 14, 6558. https://doi.org/10.3390/en14206558

Academic Editors: Antonio Barbucci and Bohung Kim

Received: 24 August 2021

Accepted: 8 October 2021

Published: 12 October 2021

Publisher's Note: MDPI stays neutral with regard to jurisdictional claims in published maps and institutional affiliations.

Copyright: (c) 2021 by the authors. Licensee MDPI, Basel, Switzerland. This article is an open access article distributed under the terms and conditions of the Creative Commons Attribution (CC BY) license (https:/ / creativecommons.org/licenses/by/ $4.0 /)$.
CIEMAT-Centro de Investigaciones Energéticas, Medioambientales y Tecnológicas, Departamento de Energía, Avda. Complutense 40, E-28040 Madrid, Spain; santacruzp.banacloche@ciemat.es (S.B.); paloma.ferreira@ciemat.es (P.F.-A.); antonio.mchaparro@ciemat.es (A.M.-C.); yolanda.lechon@ciemat.es (Y.L.) * Correspondence: daniel.garrain@ciemat.es

\begin{abstract}
A sustainability assessment regarding the manufacturing process and the use of a new proton exchange membrane fuel cell (PEMFC), specially designed for portable hydrogen applications, is presented. The initial fuel cell prototype has been configured by taking into account exclusively technical issues. However, a life cycle analysis considering environmental and socioeconomic impacts is crucial to improve the model to develop a more sustainable product. From the environmental perspective, the durability of the system and its efficiency are key elements required to decrease the potential overall impacts. High electricity consumption for manufacturing requires a commitment to the use of renewable energies, due to the high current value of the projected impact of climate change (42.5 tonnes of $\mathrm{CO}_{2} \mathrm{eq}$ ). From the socioeconomic point of view, the dependence of imported components required for the synthesis of some materials displaces the effects of value added and employment in Spain, potentially concentrating the largest impact on countries such as Singapore, Japan and the UK, whereas the cell assembly would have a greater benefit for the country of fabrication. These results provide a basis for new research strategies since they can be considered standard values for improving future upgrades of the fuel cell in terms of sustainability.
\end{abstract}

Keywords: portable power; hydrogen proton exchange membrane fuel cell; life cycle assessment; extended multi regional input-output analysis; global value chains

\section{Introduction}

Hydrogen technologies are emerging as a good solution for clean and sustainable power generation [1]. Fuel cells and electrolysers can contribute to sustainability by meeting the energy demand in a positive manner [2,3]. Although most research efforts in relation to fuel cells are concentrated on stationary and transport applications, portable power is progressively attracting more interest $[4,5]$. The fast-growing power demands of portable electronic devices are hardly satisfied by current battery technology [6]. Ziegler at al. conducted a study showing that from 1991 through 2018, the achievable energy density in batteries rose from approximately $200 \mathrm{~W} \mathrm{~h} \mathrm{~L}^{-1}$ to over $700 \mathrm{~W} \mathrm{~h} \mathrm{~L}^{-1}$, whereas the initial specific energy of $80 \mathrm{~W} \mathrm{~h} \mathrm{~kg}^{-1}$ was more than three-fold higher [7]. After 2002, Li-ion batteries have become the most promising battery technology for portable electronic devices [8].

Lithium-ion batteries are under constant development, but they still have some issues. One of these is the use of cobalt in the cathode, the production of which raises environmental and social concerns in producer countries [9]. Alternative elements such as nickel and manganese are also considered, but cobalt is still used in most batteries [10]. Lithium, on the other hand, is mainly produced in Australia, although Chile has larger reserves that cannot be mined. They must be extracted from the ground by pumping water into the earth, a process that is considered to negatively impact the environment [11]. In addition, recycling is an important aspect, considering the limited lifetime of batteries' 
components. The current recycling processes of lithium batteries produce more emissions than the production of new ones. As a result, re-use is considered preferable to recycling in the waste management hierarchy in order to extract maximum economic value and minimize environmental impacts [12]. As their market continues to grow, batteries are typically replaced when they degrade to about $80 \%$ of their original capacity in demanding applications, such as electric vehicles $[13,14]$. Although unsuitable for them, these batteries are very cost-effective for other applications, and re-use lifetimes in the range of 10 years have been estimated [15].

Despite the significant advances attained for batteries over years in terms of energy density, efficiency, durability, and safety, there is may be an inability for batteries to cope with the increasing demands of modern electronic equipment. With the rapid evolution of the portable electronics market, further advances in rechargeable batteries are expected for years to come. It has been speculated that existing batteries, including Li-ion batteries, have limited room for further improvement and that new electrochemical reactions are required to achieve a breakthrough in increasing the battery energy density [16-19].

Batteries with larger capacity are currently required in order to satisfy the increased safety requirements and power consumption of newly developed applications. Despite the advances achieved, the performance of current batteries still falls short of the demands of consumers [20]. Researchers involved in the development of future batteries hope that they can achieve energy densities two to five times higher than those currently available [21,22]. The future of power sources for these appliances will have to combine high power density, increased energy density, reliability, and short charging times [23].

The competition between the different technologies in this sector will be driven by smaller, cheaper, and lighter portable electronic devices with an increasing number of functions. These new products offer a multitude of features, including connectivity, enterprise, and multimedia capabilities. Wearable electronic devices incorporating the body's sensing, communication, and digital entertainment functions (i.e., smart watches, smart glasses, smart clothing, heart rate monitors, and fitness trackers) and unmanned aerial vehicles such as consumer drones with endless potential applied to power patrol, movie-video shooting, mobile communication, meteorology monitoring, or express delivery, creating demand for the development of new power units with a larger capacity to satisfy the increased safety requirements and power consumption. Fuel cells present a number of advantages over batteries since they provide longer operating times, wider temperature ranges, reduced environmental issues associated with disposal, and instantaneous recharge [1]. However, small portable devices are finding some technical hurdles to adapt fuel-cell-based power units to their structure due to the complexity of the auxiliary components of the fuel cell system and the low energy density of current PEMFC models [4]. A recently patented portable fuel cell model (ES1232498U, WO2020240063A1) has been especially designed for completely passive operation with minimal auxiliary systems [24]. Some of the materials used for its manufacture could be carefully selected among a number of compounds of similar properties, in the search for a more sustainable and environmentally friendly product.

Several publications indicate that fuel cells entail environmental benefits, but also exert a certain impact on the demand for non-renewable resources, in particular for so-called specialty or technology metals. Platinum is a matter of particular concern. Nowadays, PEMFC vehicles contain more platinum than combustion engine vehicles by a factor of $>10$; thus, although new cells operating at higher temperature (HT-PEMFCs) reduce their Pt loading requirements, their widespread deployment could severely aggravate the temporal and structural scarcity that is already perceptible in the global platinum market [25]. Current recovery technologies for valuable materials from fuel cells are mainly focused on the recovery of precious metals through conventional hydrometallurgical and pyro-hydrometallurgical pathways, although novel processes are being developed to recycle other relevant materials, such as carbon support and the use of ionomers from membrane-electrode assemblies [2]. As a matter of fact, the disposal and recycling of 
per- and polyfluoroalkyl substances such as those used as electrolytes (Nafion) in proton exchange membrane fuel cells (PEMFCs), commonly known as PFAS, are a matter of increasing concern, since all those substances are considered to be persistent in the environment, also implicating adverse health outcomes [26]. The monitoring of waste streams for PFAS; stopping PFAS discharges into water, soil, and air; and protecting the health of fence-line communities close to the waste disposal sites are essential to mitigating the impacts of PFAS pollution on human health [27].

In 2020, an international partnership financed by the European Union initiated the BEST4Hy H2020 projects to develop technologies for the recovery of critical raw materials from hydrogen technologies [28]. Novel recovering technologies provide enhanced technoenvironmental performance and safer operating conditions. However, further efforts are needed to reach maturity in these processes, which depends not only on technical aspects but also on the regulatory framework and the level of deployment of hydrogen fuel cell products.

Different environmental studies based on life cycle assessments (LCAs) of hydrogen fuel cells have been found in the literature. Pehnt, one of the most referenced authors of LCAs of fuel cells, carried out a complete LCA of fuel cell system components and found that this technology offers numerous advantages in terms of different environmental impacts [29] such as those related to greenhouse gases (GHG) and particle emissions. Valente and collaborators have recently published the most remarkable and interesting studies about LCA approaches on hydrogen options [2,30-38]. More specifically, Wulf and Kaltschmitt [39] developed an LCA about the supply of hydrogen and highlighted that the electrolysis used for producing hydrogen reduces GHG emissions only if the electricity comes from renewable sources compared to fossil fuel sources. Ally and Pryor [40] performed an LCA of diesel, natural gas, and hydrogen fuel cells for transportation systems and found that hydrogen fuel cells could compete with the others, since they can attain similar power although most of the impacts are lessened. Bicer and Dincer [41] analysed different aviation fuels, concluding that ammonia and hydrogen-based fuel could strongly reduce the environmental impact. Mori et al. have recently reported relevant data on materials that are the most commonly used in fuel-cell and hydrogen technologies in a criticality and life cycle assessment [42]. Finally, a study from Garraín and Lechón [43] highlighted the environmental benefits of recycling the main metals, such as platinum, tin, copper and aluminium, of a PEMFC supplied by hydrogen in a cargo-bike. Most of the LCA studies related to fuel cell technology are devoted to fuel cell electric vehicles (FCEVs) in comparison to those powered by batteries (BEVs) [44-46]. However, smaller applications powered by portable fuel cells have been scarcely studied to date.

Regarding socioeconomic studies, fuel cells are usually assessed with a focus on transport applications [47], usually considering capital expenditures (CAPEX) and operating expenditures (OPEX) costs to perform a cost-benefit analysis (CBA) [48] or both LCA and life cycle cost (LCC) studies [49]. Mehmeti and colleagues performed an LCA on fuel cells, pointing out the relevance of economic criteria in the decision-making progress and the need to employ comprehensive dynamic multi-criteria environmental impact analysis coupled with economic aspects, to allow a robust comparison of results [50]. Estimating the total, direct, and indirect effects of fuel cells on economic growth and employment through the input-output approach would enrich the sustainability assessment. To our knowledge, no economic assessment of fuel cells has been undertaken in regard to this methodology.

\section{Objective}

The objective of this study was to assess the behavior of the manufacturing process and the use of a new, recently patented (ES1232498U) portable fuel cell prototype from a sustainability perspective. This model is representative of a new generation of fuel cells specially designed for small devices, which are currently under development. It is therefore an original and pioneering study for the development of new disruptive PEMFC models for portable applications, which is aimed at presenting several environmental and 
socio-economic quantitative indicators. These results will be considered as standard values for improvements in future upgrades of the fuel cell prototype.

\section{Technical Description of the Fuel Cell}

The new PEMFC is a development intended to attain power densities comparable with modern Li-ion batteries in portable applications where conventional PEMFCs cannot operate. As a difference from a conventional PEMFC prototype, the developed cell works with fully passive feeding, instead of convective feeding, which decreases the power delivered but improves the overall power density of the system.

The fuel cell has a modified design, aiming to improve the portability of a power production device based on hydrogen [24]. An exploded view of the cell is shown in Figure $1 \mathrm{a}$ and a photograph of a cell of $5 \mathrm{~cm}$ in diameter $(3 \mathrm{~cm}$ in diameter for circular electrodes with an active area of $7.1 \mathrm{~cm}^{2}$ ) is presented in Figure $1 \mathrm{~b}$. The anode, where hydrogen reacts, is based on a gas-diffusion electrode (GDE) with a nickel grid as current collector and a polyether ether ketone (PEEK) end-plate with hydrogen inlet and outlet ports. It is able to operate under full dead-end conditions, i.e., without any purging, thanks to a water-permeable window implemented at the back of the anodic plate which is able to permeate the excess water. By these means, the cell attains $100 \%$ faradaic efficiency, which means that all the stored hydrogen is used to produce the electric current without wastage. The cathode is an open-air, air-breathing cathode, based on a GDE, a nickel grid current collector, and a columnar aluminum plate opened to the ambience. The electrolyte is a Nafion-based proton exchange membrane (PEM), typically Nafion 212NR (Ion Power).

a)

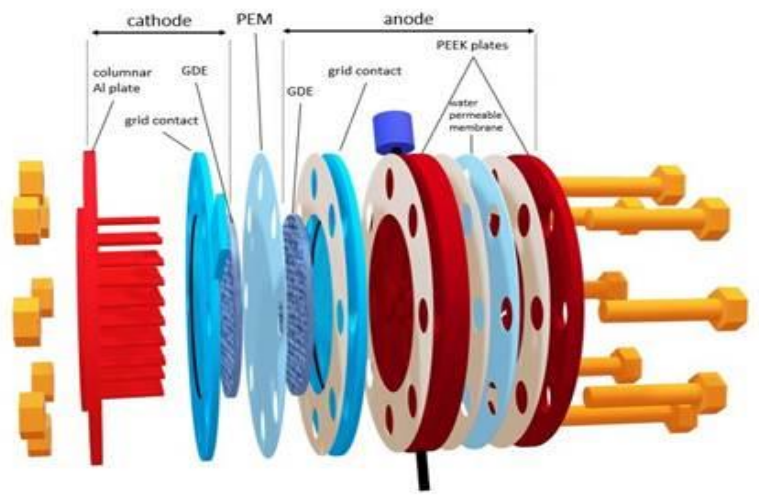

c)

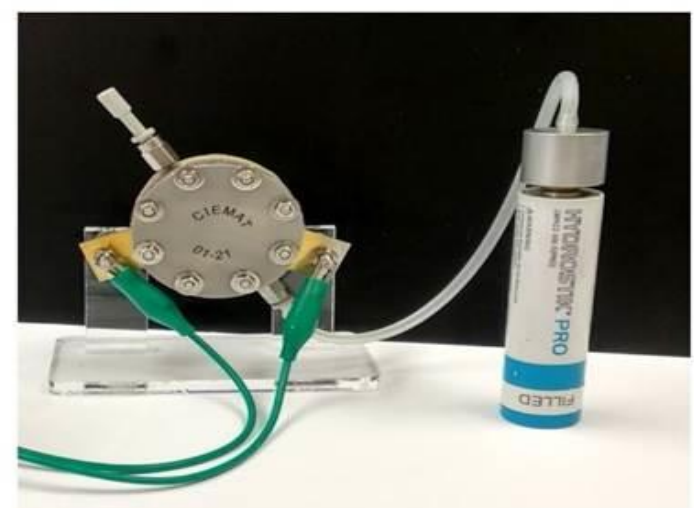

b)

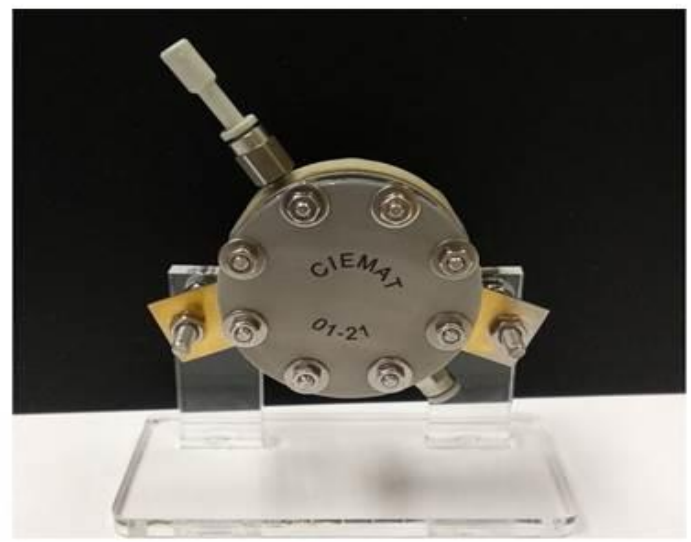

d)

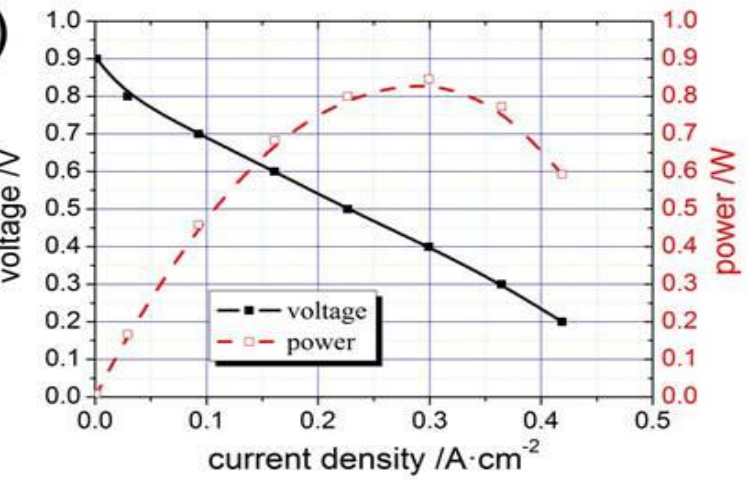

Figure 1. (a) Exploded view of the portable PEMFC; (b) front view of the cell (5 cm diameter); (c) view of the cell and hydrogen cartridge for portable applications; (d) stabilized polarization curve and power delivered.

Gold-coated nickel grids are used as current collectors in this type of air-breathing fuel cell to allow for the rapid entrance of environmental air by natural convection and without forced ventilation. They also provide a good solution through the use of light plastic 
plates at the anode. Nickel is a good conductor and a relatively cost-effective material. In case of the oxidation of this substrate due to gold-coating defects or pores, nickel forms a passivating oxide that limits the release of nickel ions to the electrodes [51]. The presence of free cations in the cell could contribute to poisoning the proton exchange membrane or the ionomer in the electrodes and reducing the proton conductivity and therefore the cell performance [52].

The cell is able to operate under passive conditions; therefore, no convective forces are necessary for reactant gases during power production, and the system delivers up to $0.14 \mathrm{~W} \mathrm{~cm}^{-2}$, referring to the active area (Figure 1d). The hydrogen fuel cell system is completed with a hydrogen storage system connected to the cell by means of a pressure regulator ( 0.8 bar), as shown in Figure 1c. The hydrogen storage system considered in this analysis is based on a commercial metal-hydride canister with a storage capacity of $1 \mathrm{~g} \mathrm{H}_{2}$ at 30 bar pressure (Hydrostik Pro) that can be refilled by means of a laboratory electrolyzer. This hydrogen reservoir provides energy for $15 \mathrm{~W}$ h consumption, considering a total fuel cell conversion efficiency of $50 \%$. This hydrogen storage element has been considered for the analysis of the complete system, although it could be replaced by other $\mathrm{H}_{2}$ storage and dispensing systems without affecting the fuel cell prototype.

\section{Material and Methods}

\subsection{Life Cycle Assessment}

One of the tools most widely accepted by the scientific community to assess the potential environmental impact is the LCA, an analytical procedure that assesses the complete life cycle of a service, process or product, regulated by the International Organization for Standardization (ISO) standards [53,54]. The main stages in the methodology are: definition of the goal and scope, the life cycle inventory (LCI), the life cycle impact assessment (LCIA), and interpretation of the results.

The goal of this study is to develop environmental indicators of the manufacturing and use stages of the new PEMFC through an attributional LCA approach. Then, the end-of-life stage is excluded. The manufacturing processes of each material have been included and transports are excluded because of their negligible value. The functional unit for presenting the results is the consideration of the useful life of the PEMFC. Figure 2 shows the system's boundaries, including the inputs and the considered stages of the process.

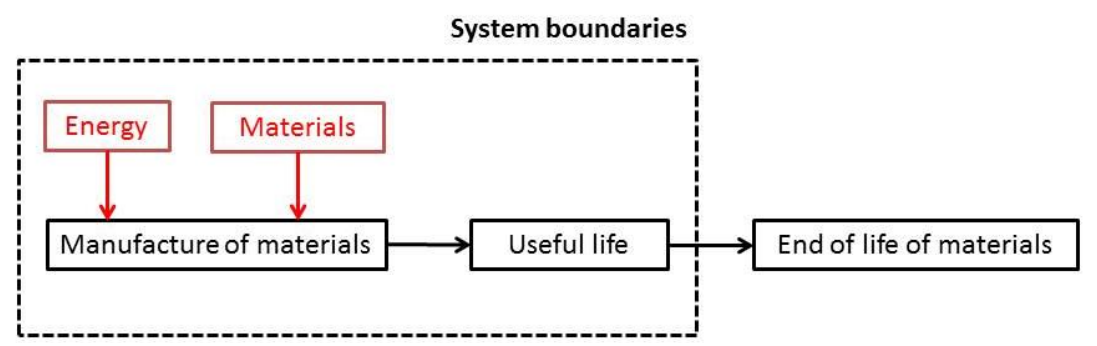

Figure 2. PEMFC system boundaries considered in the LCA.

In order to carry out the material inputs to fulfil the LCI analysis, the second stage of the LCA methodology, it is necessary to consider the fuel cell and the hydrogen reservoir. As previously described in Section 3, the fuel cell can be divided into the anode, the membrane, and the cathode. It is also necessary to consider the cell locks, and the gas connectors. Table 1 shows the main materials for manufacturing the fuel cell of $1 \mathrm{~W}$ power. The values used were the most up-to-date values in the database, in which data before 2010 have not been considered. Table 2 shows the inventory source of each material, in which PEEK was characterized. 
Table 1. LCI of the fuel cell infrastructure.

\begin{tabular}{cccc}
\hline Part & Component & Material & Weight (g) \\
\hline & Anodic plate 1 & PEEK & 6.567 \\
& Anodic plate 2 & PEEK & 9.175 \\
& Membrane 1 & Nafion (Nf117) & 0.305 \\
Anode & Junction 1 & Silicone & 0.079 \\
& Lock 1 & Stainless steel (screws and washers) & 2.183 \\
& Junction 2 & Silicone & 0.283 \\
& Junction 3 & Silicone & 0.497 \\
& Frame 1 & PET-G (20\% carbon fiber) & 1.162 \\
& Grille 1 & Nickel & 0.397 \\
& Electrode 1 & Charcoal cloth + Pt (Pt/C) & 0.151 \\
\hline Membrane & Membrane 2 & Nafion (Nf112) & 0.293 \\
\hline \multirow{4}{*}{ Cathode } & Junction 4 & PET film (Mylar $\left.{ }^{\circledR}\right)$ & 0.069 \\
& Electrode 2 & Charcoal cloth + Pt (Pt/C) & 0.156 \\
& Frame 2 & PET-G (20\% carbon fiber) & 1.161 \\
& Frame 3 & Aluminium & 2.278 \\
& Grille 2 & Nickel & 0.399 \\
& Cathodic plate & Aluminum & 17.086 \\
\hline \multirow{2}{*}{ Cell locks } & Lock 2 & Steel & 8.060 \\
& Lock 2 & Steel & 2.513 \\
\hline Gas connectors & Two gas connectors & Reinforced glass fiber & 5.424 \\
\hline
\end{tabular}

On the other hand, the hydrogen reservoir consists of a commercial metal-hydride storage system. It is a cylinder with $5 \mathrm{~g}$ of aluminum coating, and $99 \mathrm{~g}$ of a metal hydride $\left(\mathrm{LaNi}_{5}\right)$, which may absorb up to $1 \mathrm{~g}$ of hydrogen at room temperature, which is equivalent to $15 \mathrm{~W}$ h of net electricity produced by the fuel cell ( $50 \%$ efficiency is assumed, according to personal communications from the technical staff). The hydrogen can be produced by a laboratory-scale hydrolyzer with the following characteristics: $3 \mathrm{~L} \mathrm{~h}^{-1}, 20 \mathrm{~W}$, and $70 \%$ efficiency. The fuel cell power may attain up to $40,000 \mathrm{~h}$ of lifetime if operated in constant current load, but the durability decreases to approximately $5000 \mathrm{~h}$ under variable power production due to accelerated degradation by start-up and shut-down events, and to fast changes in the power demand.

Based on an LCA approach, the European Commission (EC) developed a harmonized impact assessment method called the environmental footprint (EF) for both products and organizations [55]. EF provides a method for modelling the environmental impact of material and energy flows and emissions and waste flows associated with a product throughout its life cycle. In addition, it ofers guidance on how to establish methodological requirements for specific categories of products intended for use in the Product Environmental Footprint Category Rules (PEFCR). These impact categories are generally related to the use of resources and the emissions flows affecting both human health and ecosystems. The EF guide recommends the categories developed using the International LifeCycle Datasystem (ILCD) 2011 midpoint method [56].

\subsection{Multi-Regional Input-Output Assessment}

The input-output methodology [57] has also been used to estimate the impacts that the fuel cell investment could have in terms of economic growth (value added) and employment creation. This methodology uses input-output tables, a macroeconomic tool which describes the sale and purchase relationships between producers and consumers within an economy. The input-output methodology allows the estimation of the total (direct and indirect) economic stimulation produced by an increase in the demand for goods and services. Moreover, socioeconomic impacts such as value added and employment can be addressed, pointing out the country and sector origin where economic effects are 
being produced. Working with multi-regional input-output tables (MRIOT), the trade interdependence among sectors and countries can also be captured [58].

Table 2. Inventory sources considered for the materials.

\begin{tabular}{|c|c|c|}
\hline Material & Input & Database \\
\hline \multirow[t]{16}{*}{ PEEK } & Hydroquinone, RER, prod, Alloc Def & Ecoinvent \\
\hline & Potassium carbonate, at plant GLO & Ecoinvent \\
\hline & Toluene, at plant, RER & Industry data 2.0 \\
\hline & Electricity, med volt, prod ES, at grid & Ecoinvent \\
\hline & Natural gas, burned, ES & Ecoinvent \\
\hline & Benzyl chloride, at plan, RER & Ecoinvent \\
\hline & Chlorine gas, production mix, RER & Agri-footprint \\
\hline & Aluminium, primary, ingot, GLO, Alloc En & Ecoinvent \\
\hline & Hydrochloric acid, $36 \%$ in $\mathrm{H} 2 \mathrm{O}$, from reacting & Ecoinvent \\
\hline & Aniline, at plant, RER & Ecoinvent \\
\hline & Lead, primary, at plant, GLO & Ecoinvent \\
\hline & $\begin{array}{c}\text { Sodium hydroxide, } 50 \% \text { in } \mathrm{H} 2 \mathrm{O} \text {, production mix, } \\
\text { at plant, RER }\end{array}$ & Ecoinvent \\
\hline & Nitric acid, ETH & ETH-ESU \\
\hline & Ammonia, liquid, at reg storehouse, $\mathrm{CH}$ & Ecoinvent \\
\hline & Boric acid, anhydrous, at plant, RER & Ecoinvent \\
\hline & Hydrogen fluoride, at plant, GLO & Ecoinvent \\
\hline \multirow{2}{*}{$\begin{array}{l}\text { Nafion } \\
\text { Silicone }\end{array}$} & Tetrafluoroethylene, at plant, RER & Ecoinvent \\
\hline & Silicone product, at plant, RER & Ecoinvent \\
\hline \multirow{2}{*}{ Stainless steel } & X12Cr13 (416) I & IDEMAT \\
\hline & Hot rolling, steel, RER & Ecoinvent \\
\hline \multirow{2}{*}{ PET-G } & Polyethylene terephthalate (PET) granulate, production & ELCD \\
\hline & Carbon fiber I & IDEMAT \\
\hline Nickel & Nickel, $99.5 \%$, at plant, GLO & Ecoinvent \\
\hline \multirow{2}{*}{ Charcoal cloth } & $\begin{array}{c}\text { Phosphoric acid, industrial grade, } 85 \% \text { in } \mathrm{H} 2 \mathrm{O}, \\
\text { at plant, RER }\end{array}$ & Ecoinvent \\
\hline & Textile, woven cotton, at plant, GLO & Ecoinvent \\
\hline \multirow{2}{*}{ Steel } & Reinforcing steel, at plant, RER & Ecoinvent \\
\hline & Rolling steel I & IDEMAT \\
\hline \multirow[t]{2}{*}{ Glass fiber } & $\begin{array}{l}\text { Glass fibre reinforced plastic, polyester resin, hand } \\
\text { lay-up, at plant, RER }\end{array}$ & Ecoinvent \\
\hline & Extrusion, plastic pipes, RER & Ecoinvent \\
\hline
\end{tabular}

For this analysis, the Organization for Economic Cooperation and Development's inter-country input-output (OECD-ICIO) tables [59] have been used, in view of the most recent edition based on International Standard Industrial Classification (ISIC) Revision 4 [60]. This database provides a time series of 69-region and 36-sector symmetric industryby-industry MRIOTs with matching employment satellite accounts [61]. The present study aggregates the MRIOTs for the year 2015 into seven regions (Spain, Germany, the UK, Japan, Singapore, the United States and the rest of the world), considering the countries that are directly involved in the manufacturing of the components needed for assembling the fuel cell. The impacts calculated are expressed by the following matrix equation:

$$
F_{H}=\hat{f}(I-A)^{-1} Y_{H}
$$

where $F_{H}$ indicates the total socioeconomic effects (value added and employment) of investing in the fuel cell, $\hat{f}$ denotes the diagonalized socioeconomic vector (value added/employment per unit of output), $(I-A)^{-1}$ is the Leontief inverse, and $Y_{H}$ represents the direct in- 
vestments (components) of the fuel cell. The Leontief inverse can be understood as the multiplier effect and provides information about the total stimulation produced from both direct and indirect effects produced by each direct monetary unit invested in the project [62] This approach has been widely used in assessing energy investments at a country-level [63] or considering commercially feasible investments that account for considerable amounts of money [64]. However, it is not common to apply this methodology to early-stage sciencedriven prototypes, as could be the case for the portable fuel cell in this study. Hence, the results here must be addressed carefully. However, this methodology has the advantage of identifying global value chains and the indirect impacts that arise as a carry-over effect.

In this analysis, the hydrogen fuel cell of $1 \mathrm{~W}$ power has been considered. The material cost data of the manufacturing phase using prices from commercial suppliers in Madrid (Spain) are shown in Table 3, as well as the corresponding origin country.

Table 3. Investment cost disaggregation and supplier countries.

\begin{tabular}{cccc}
\hline Component & Investment Cost Breakdown & Country & $\boldsymbol{\epsilon}_{\mathbf{2 0 1 8}}$ \\
\hline & & $\mathbf{3 4 . 1 5}$ \\
PEEK & UK & 11.76 \\
Nickel grid & United States & 0.70 \\
Steel & Spain & 0.10 \\
Silicone & Spain & 0.10 \\
& Membrane & 4.00 \\
Gell & Screws & United States & 4.55 \\
& Washers & Spain & 0.08 \\
& Nuts & Spain & 0.08 \\
& M2 screws & Spain & 0.08 \\
M2 washers & Spain & 0.08 \\
& Spain & 0.08 \\
& Stainless steel (Helicoil $\left.{ }^{\circledR}\right)$ & Spain & 2.32 \\
Gas connectors $(2)$ & Japan & 5.20 \\
Aluminium dissipater & Germany & 5.01 \\
\hline Hydrogen Metals-Hydride Container $\left(\mathrm{H}_{2}\right.$ reservoir) & Singapore & 40.00 \\
\hline Portable System & & $\mathbf{4 7 . 0 0}$ \\
Pressure control & Japan & 22.00 \\
& Conduits and connectors & Spain & 5.00 \\
DC-DC conversion & UK & 22.00 \\
\hline TOTAL & & $\mathbf{1 2 1 . 1 5}$ \\
\hline
\end{tabular}

Once material costs have been accounted for, the investments needed to produce the fuel cell (final goods and services required) are allocated to the corresponding economic sectors and countries on the input-output table (i.e., the gas connectors produced in Japan are included in the computer, electronic, and optical products sector). This allows us to construct the demand vector, which correspond to the direct effects, which will be later used to calculate the indirect effects. Table 4 shows the final demand vector, which is the total investment costs assigned to the corresponding economic sectors of each country. Costs have been converted into USD and brought to 2015 prices.

Once the demand vector is constructed, it can be multiplied by the Leontief inverse matrix to obtain the indirect effects, estimating the total demand of goods and services of each phase. 
Table 4. Demand vector.

\begin{tabular}{ccc}
\hline Country & Sector & Investment Costs $\mathbf{( \$ \mathbf { 2 0 1 5 }}$ ) \\
\hline Singapore & Electrical equipment & 46.01 \\
Japan & Computer, electronic and optical products & 31.29 \\
UK & Electrical equipment & 23.01 \\
UK & Chemicals and pharmaceutical products & 13.53 \\
United States & Electrical equipment & 9.84 \\
Germany & Electrical equipment & 5.76 \\
Spain & Electrical equipment & 5.75 \\
Spain & Basic metals & 2.78 \\
United States & Basic metals & 0.81 \\
Spain & Fabricated metal products & 0.46 \\
Spain & Chemicals and pharmaceutical products & 0.12 \\
\hline
\end{tabular}

\section{Results and Discussion}

\subsection{Environmental Indicators}

Table 5 shows the total environmental impact of both the fuel cell and the hydrogen cartridge when the total useful life is considered, according to the LCIA stage of the LCA methodology. Due to the high number of hydrogen cartridges consumed, the influence of the infrastructure is less than $1 \%$ in the majority of impact categories. Nevertheless it is important to take into account an exploratory analysis of this subject in order to identify the hotspots for improving new materials. Figure 3 shows the contribution of each part in the impact categories. Anodes are the main contributors to the EF because of their composition. Anodic plates are made of PEEK, a material of which the production is nowadays highly electricity-consuming because it must be manufactured at the labscale. The electricity consumption of the PEEK manufacturing process is expected to be optimized when produced at the market-scale and additionally the electricity generation mix is expected to be further decarbonized in the future. Both factors will lead to a decrease in the EF results. Additionally, further modifications of the hydrogen-powered fuel cell prototype could also consider using alternatives to these elements to develop a power unit with the lowest possible EF.

Table 5. EF results of the manufacturing and useful life of the fuel cell and the percentage contributions of the fuel cell infrastructure versus hydrogen cartridges.

\begin{tabular}{|c|c|c|c|c|}
\hline Impact Category & Unit* & Total Value & $\%$ Fuel Cell & $\%$ Cartridges \\
\hline Climate change (CC) & $\mathrm{kg} \mathrm{CO} 2 \mathrm{eq}$ & 42,500 & 0.19 & 99.81 \\
\hline Ozone depletion (OD) & $\mathrm{kg}$ CFC-11 eq & 0.15 & 0.11 & 99.89 \\
\hline Human toxicity, non-cancer effects (HHnc) & $\mathrm{CTU}_{\mathrm{h}}$ & $3.7 \times 10^{-3}$ & 0.47 & 99.53 \\
\hline Human toxicity, cancer effects $(\mathrm{HHc})$ & $\mathrm{CTU}_{\mathrm{h}}$ & $7.8 \times 10^{-4}$ & 0.16 & 99.84 \\
\hline Respiratory inorganics, particulate matter (RI) & Disease incidence & $1.4 \times 10^{-3}$ & 0.21 & 99.79 \\
\hline Ionizing radiation (IR) & $\mathrm{kBq} \mathrm{U}^{235} \mathrm{eq}$ & 18,800 & 0.04 & 99.96 \\
\hline Photochemical ozone formation (PO) & $\mathrm{kg}$ NMVOC eq & 135.5 & 0.17 & 99.83 \\
\hline Acidification $(\mathrm{AC})$ & molc $\mathrm{H}^{+}$eq & 443 & 0.11 & 99.89 \\
\hline Terrestrial eutrophication (EuT) & molc $\mathrm{N}$ eq & 461 & 0.17 & 99.83 \\
\hline Freshwater eutrophication (EuF) & $\mathrm{kg} \mathrm{P} \mathrm{eq}$ & 20 & 0.08 & 99.92 \\
\hline Marine eutrophication (EuM) & $\mathrm{kg} \mathrm{N} \mathrm{eq}$ & 45 & 0.15 & 99.85 \\
\hline Freshwater ecotoxicity (EcF) & $\mathrm{CTU}_{\mathrm{e}}$ & 16,500 & 0.27 & 99.73 \\
\hline Land use (LU) & $\mathrm{Pt}$ & 33,400 & 0.12 & 99.88 \\
\hline Water scarcity (WS) & $\mathrm{m}^{3}$ water world eq & $\begin{array}{c}1.19 \times 10^{7} \\
1.2 \times 10^{7}\end{array}$ & 0.08 & 99.92 \\
\hline Resource use (mineral and metals) (Rmm) & $\mathrm{kg} \mathrm{Sb} \mathrm{eq}$ & 0.05 & 4.82 & 95.18 \\
\hline Resource use (energy and fossils) (Ren) & MJ & $\begin{array}{c}6.26 \times 10^{5} \\
6.3 \times 10^{5}\end{array}$ & 0.19 & 99.81 \\
\hline
\end{tabular}

\footnotetext{
${ }^{*} \mathrm{CTU}_{\mathrm{h}, \mathrm{e}}$ : Comparative toxic units (human, ecosystem).
} 


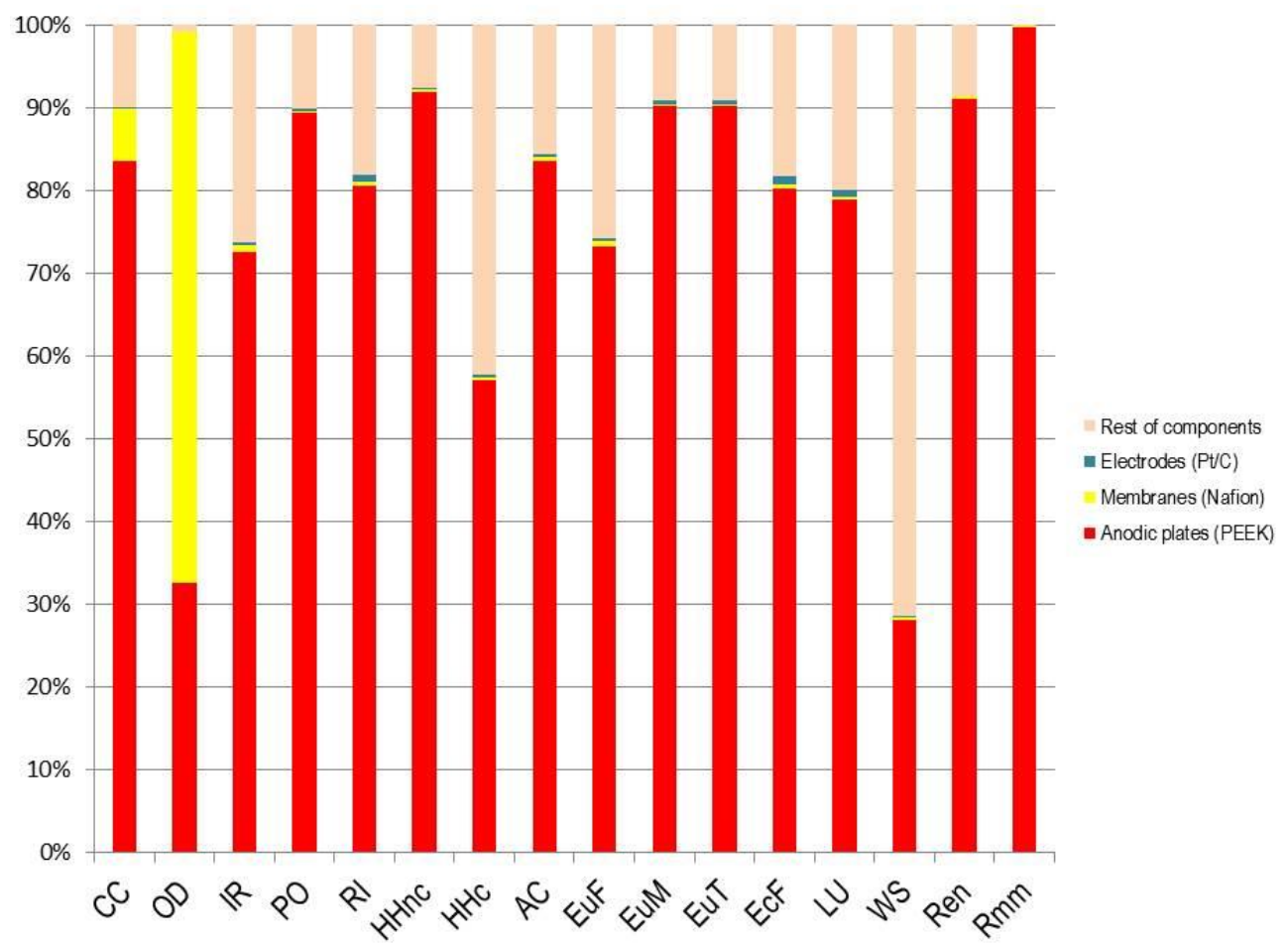

Figure 3. Relative contribution to the EF of the different components of the fuel cell of $1 \mathrm{~W}$ power.

Figure 4 shows the EF percentages and composition of the cartridge and the hydrogen stored within it. The major impact from the cartridge is attributed to the metal hydride because of the higher amount of aluminum. Aluminum production is also very energyintensive. The electricity consumption in aluminum production has been reduced in recent years and is expected to be further optimized. Additionally, electricity mixes around the world will increasingly make use of renewable energies, reducing the overall EF of the cartridge.

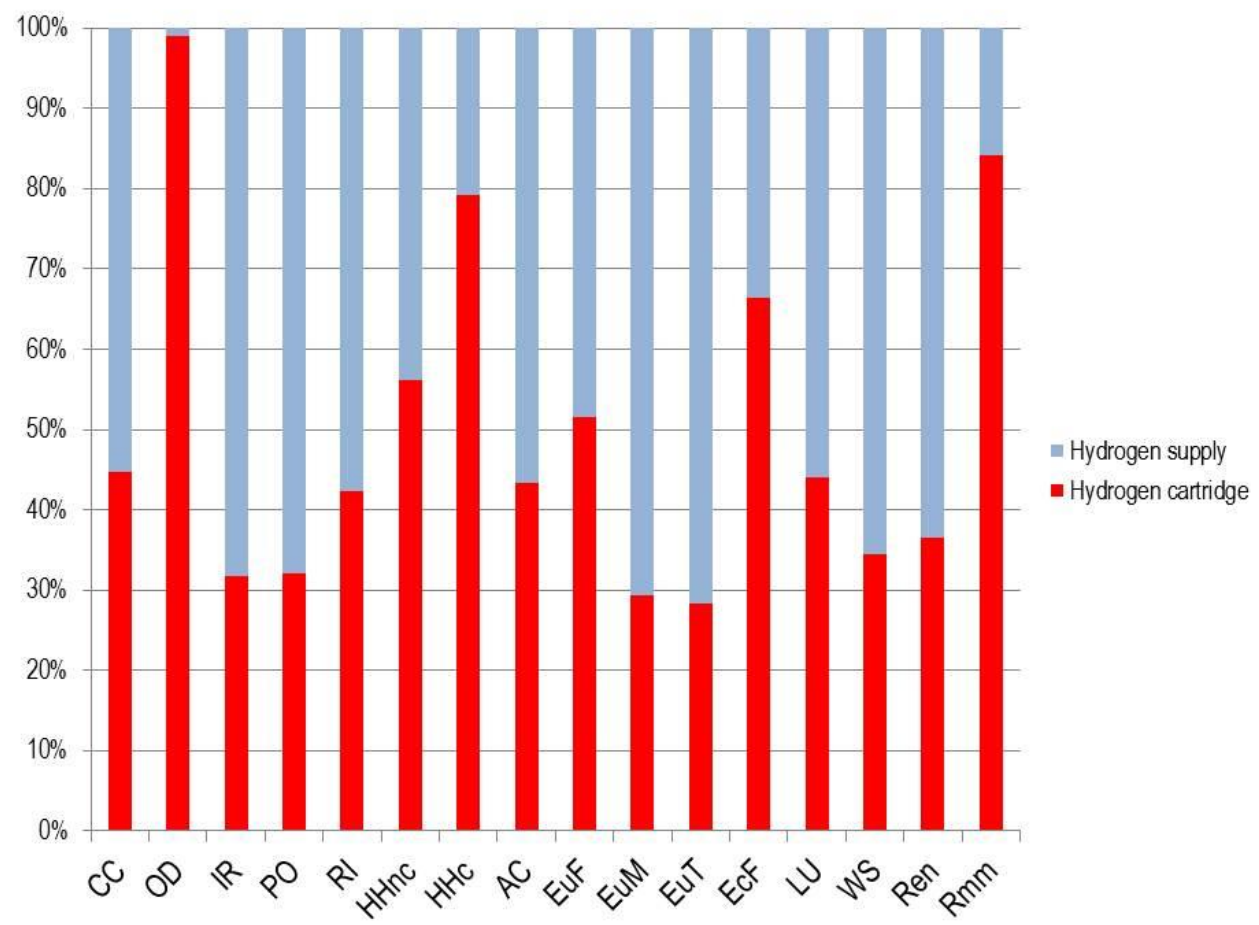

Figure 4. Relative contribution to the EF of the hydrogen cartridge and supply. 
The environmental effects of the hydrogen supply are due to the high amount of electricity consumed by the electrolyzer during the generation process, due to its small scale for domestic use. However its EF would depend on the region of the world where the system was recharged.

On the other hand, electricity consumption associated with the manufacturing stage of the prototype is a very important hotspot, which is largely affected by the laboratory-scale production of the initial model.

\subsection{Socio-Economic Indicators}

The multiplier effect on the production of one fuel cell in the priority country (Spain) is estimated to be 2.42 times the effect on the demand for the components. However, socioeconomic effects of the manufacture of this fuel cell would mainly have an impact abroad, both in terms of economic growth and employment, due to the special technology required for the production of new materials and import dependency of the components (i.e., the hydrogen container). The global value chain (GVC) phenomenon, where a final product is created across different countries, determines the functioning of production processes nowadays, with impacts on value added and job creation. In this study, domestic manufacturing of components accounts for $6.5 \%$ of the initial investment. However, other actors arise when considering a boost in production, value added, and jobs, displacing Spain's participation. Only 5.6\%, $4.5 \%$, and $2.4 \%$ of the effects would have an impact domestically, respectively. The initial investment depends on imported components and this is more severe when looking at value adding and especially at employment (see Figure 5).

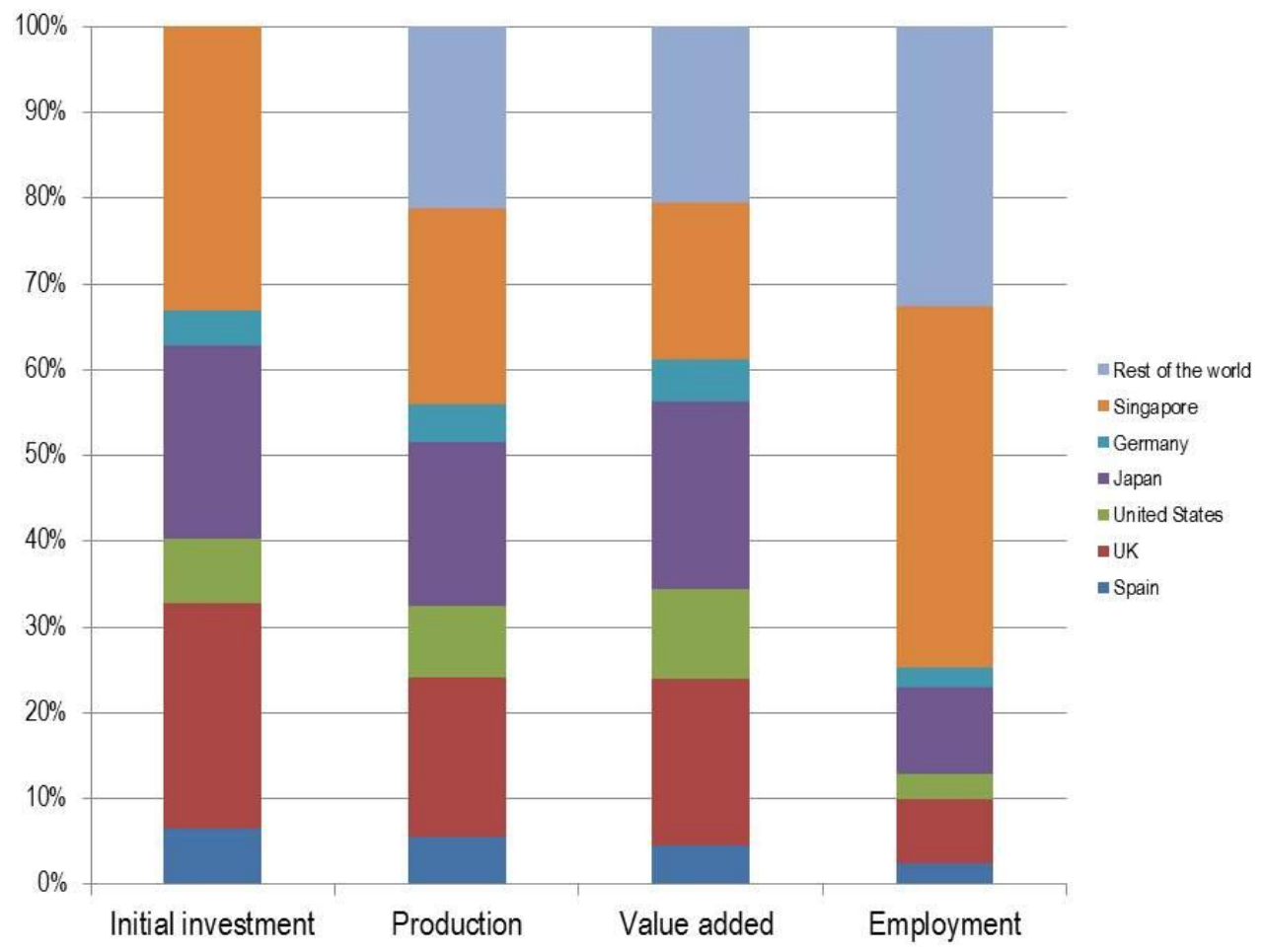

Figure 5. Socioeconomic impacts. The initial investment (understood as final demand) increases across the countries (via intermediates), adding value and generating employment throughout all the stages of production.

The main economic sectors responsible for the largest shares of the three types of socioeconomic effects analyzed are displayed in Figure 6. Singapore becomes the most benefited country, where value added and employment are created in electrical equipment activities related to the hydrogen metal-hydride container, which has been considered here as hydrogen storage medium, although possible alternatives could also be considered. Many relevant sectors and regions where no initial investment has been made become 
important providers of intermediates and appear to benefit the most in terms of production, value added and employment (sectors shown in bold) due to GVC: extractive activities coming from the "rest-of-the-world" region need to be performed to produce the intermediates required for the final components.

\begin{tabular}{|c|c|c|c|c|}
\hline Country & Economic sector & $\begin{array}{l}\text { Production } \\
\text { (USD) }\end{array}$ & $\begin{array}{l}\text { Value added } \\
\text { (USD) }\end{array}$ & $\begin{array}{l}\text { Jobs (per } \\
\text { M.USD) }\end{array}$ \\
\hline \multirow{2}{*}{$\begin{array}{l}\text { Singapore } \\
\text { Japan }\end{array}$} & \multirow{2}{*}{$\begin{array}{l}\text { Electrical equipment } \\
\text { Computer, electronic and optical products }\end{array}$} & 46.376 & 12.742 & 0.68 \\
\hline & & 34.689 & 15.042 & 0.14 \\
\hline \multirow{3}{*}{$\begin{array}{l}\text { UK } \\
\text { UK } \\
\text { United States }\end{array}$} & \multirow{2}{*}{$\begin{array}{l}\text { Electrical equipment } \\
\text { Chemicals and pharmaceutical products }\end{array}$} & 23.494 & 8.757 & 0.09 \\
\hline & & 15.261 & 5.918 & 0.02 \\
\hline & Electrical equipment & 10.277 & 4.621 & 0.03 \\
\hline \multirow{2}{*}{$\begin{array}{l}\text { Rest of the World } \\
\text { Germany }\end{array}$} & Basic metals & 9.014 & 1.755 & 0.05 \\
\hline & Electrical equipment & 6.663 & 2.758 & 0.03 \\
\hline Spain & Electrical equipment & 6.089 & 1.657 & 0.02 \\
\hline Rest of the World & Wholesale and retail trade; repair of motor vehicles & 5.855 & 3.366 & 0.21 \\
\hline Rest of the World & Other business sector services & 5.495 & 2.874 & 0.11 \\
\hline Rest of the World & Mining and extraction of energy producing products & 5.251 & 3.063 & 0.03 \\
\hline Japan & Wholesale and retail trade; repair of motor vehicles & 4.543 & 2.979 & 0.06 \\
\hline Singapore & Other business sector services & 4.621 & 2.282 & 0.18 \\
\hline Singapore & Wholesale and retail trade; repair of motor vehicles & 2.687 & 1.198 & 0.18 \\
\hline Rest of the World & Transportation and storage & 5.031 & 2.168 & 0.12 \\
\hline Rest of the World & Agriculture, forestry and fishing & 0.844 & 0.455 & 0.12 \\
\hline Singapore & Transportation and storage & 3.247 & 0.795 & 0.10 \\
\hline
\end{tabular}

Figure 6. The main economic sectors responsible for the largest shares of socioeconomic effects.

\section{Conclusions}

First, the environmental and socioeconomic results of the manufacturing and use stages of a new portable fuel cell prototype, according to the utility model ES1232498U, using hydrogen fuel have been presented.

By considering the manufacturing of a Spanish $\mathrm{H}_{2}$-fuel cell system for the portable devices analyzed, it can be concluded that hydrogen supply and storage is the most critical element in the power system.

The electrolyzer used for the hydrogen supply has been considered to work with the Spanish electricity mix, which still uses some fossil technologies. The expected full decarbonization of the electricity production in Spain (and in Europe) by the midcentury will decrease the environmental impacts associated to the production of hydrogen for the fuel cell to a large extent. It would also be possible that the device could be operated using only a renewable energy source, thus reducing the environmental impacts.

The EF of the cartridge production can also be greatly reduced if renewable electricity is used in the aluminum production process.

Regarding the manufacturing of the fuel cell, the anodic plates, which are made of a high-performance engineering plastic with outstanding resistance to harsh chemicals, and excellent mechanical strength and dimensional stability, are the main contributors to the environmental footprint. Consequently, further modifications of the hydrogen-powered fuel cell prototype will consider using alternatives to these elements to develop a power unit with a small EF and positive impacts in domestic added value, manufacturing, and job creation.

Overall, there are many avenues for EF reductions in the manufacturing and use of the analyzed $\mathrm{H} 2$ fuel cell system for portable devices. In order to decrease the high electricity consumption required for the manufacturing process, a future potential (semi)industrialscale process could improve the efficiency of the system and reduce its impacts. Additionally, the abovementioned decarbonization of electricity production will also contribute to reducing these impacts. In the use of the cell, the assumption of $5000 \mathrm{~h}$ of useful time 
is considered a pessimistic scenario for the first prototype, so it would be necessary to improve its durability and its efficiency in order to decrease all of its potential impacts.

From the socioeconomic perspective, the fragmentation of production among countries determines the benefits in terms of value added and employment creation. In this case, the high dependency on imported components undermines the domestic value added and the employment creation that are produced in the manufacturing countries. Ceteris paribus, jobs related to the fuel cell assembly process remain the only option to boost employment domestically. For the PEMFC-producing country, it could be convenient to address this problem through policies to boost the manufacturing of components locally (i.e., fostering a home-grown industry or searching for substitute components), thus benefitting to a higher extent by retaining more value added and jobs.

There is no possibility of comparing the quantitative results of the developed indicators with other fuel cells due to their small scale and exclusive function. Nevertheless, new developments and improvements will be carried out in a follow-up project for portable applications, intending to improve the power density and reliability of the cells, considering the results of this analysis.

Author Contributions: Conceptualization, D.G. and S.B.; methodology, D.G. and S.B.; formal analysis, D.G. and S.B.; investigation, D.G., S.B., and Y.L.; resources, P.F.-A. and A.M.-C.; data curation, P.F.-A. and A.M.-C.; writing—original draft preparation, D.G., S.B., P.F.-A., and A.M.-C.; writingreview and editing, Y.L.; visualization, D.G.; supervision, Y.L.; project administration, P.F.-A. and A.M.-C.; funding acquisition, P.F.-A. and A.M.-C. All authors have read and agreed to the published version of the manuscript.

Funding: This research was funded by the Spanish Ministry of Science and Innovation by means of the ELHYPORT project (PID2019-110896RB-I00), a four-year project.

Institutional Review Board Statement: Not applicable.

Informed Consent Statement: Not applicable.

Conflicts of Interest: The authors declare no conflict of interest.

\section{References}

1. Alaswad, A.; Omran, A.; Sodre, J.R.; Wilberforce, T.; Pignatelli, G.; Dassisti, M.; Baroutaji, A.; Olabi, A.G. Technical and commercial challenges of proton-exchange membrane (PEM) fuel cells. Energies 2020, 14, 144. [CrossRef]

2. Valente, A.; Iribarren, D.; Dufour, J. End of life of fuel cells and hydrogen products: From technologies to strategies. Int. J. Hydrogen Energy 2019, 44, 20965-20977. [CrossRef]

3. Pethaiah, S.S.; Sadasivuni, K.K.; Jayakumar, A.; Ponnamma, D.; Tiwary, C.S.; Sasikumar, G. Methanol electrolysis for hydrogen production using polymer electrolyte membrane: A mini-review. Energies 2020, 13, 5879. [CrossRef]

4. Ferreira-Aparicio, P. Technology indicators of portable power based on hydrogen-fed fuel cells. In Portable Hydrogen Energy Systems; Elsevier: Amsterdam, The Netherlands, 2018; pp. 175-192.

5. Sapkota, P.; Boyer, C.; Dutta, R.; Cazorla, C.; Aguey-Zinsou, K.-F. Planar polymer electrolyte membrane fuel cells: Powering portable devices from hydrogen. Sustain. Energy Fuels 2020, 4, 439-468. [CrossRef]

6. Costa, C.; Lizundia, E.; Lanceros-Méndez, S. Polymers for advanced lithium-ion batteries: State of the art and future needs on polymers for the different battery components. Prog. Energy Combust. Sci. 2020, 79, 100846. [CrossRef]

7. Ziegler, M.S.; Trancik, J.E. Re-examining rates of lithium-ion battery technology improvement and cost decline. Energy Environ. Sci. 2021, 14, 1635-1651. [CrossRef]

8. Nitta, N.; Wu, F.; Lee, J.T.; Yushin, G. Li-ion battery materials: Present and future. Mater. Today 2015, 18, 252-264. [CrossRef]

9. Handwerker, M.; Wellnitz, J.; Marzbani, H. Comparison of hydrogen powertrains with the battery powered electric vehicle and investigation of small-scale local hydrogen production using renewable energy. Hydrogen 2021, 2, 5. [CrossRef]

10. Li, M.; Lu, J. Cobalt in lithium-ion batteries. Science 2020, 367, 979-980. [CrossRef]

11. Jaskula, B.W. Mineral Commodity Summaries; U.S. Geological Survey: Reston, VA, USA, 2021.

12. Harper, G.; Sommerville, R.; Kendrick, E.; Driscoll, L.; Slater, P.; Stolkin, R.; Walton, A.; Christensen, P.; Heidrich, O.; Lambert, S.; et al. Recycling lithium-ion batteries from electric vehicles. Nature 2019, 575, 75-86. [CrossRef]

13. Li, H.; Alsolami, M.; Yang, S.; Alsmadi, Y.M.; Wang, J. Lifetime test design for second-use electric vehicle batteries in residential applications. IEEE Trans. Sustain. Energy 2017, 8, 1736-1746. [CrossRef]

14. Second-life Electric Vehicle Batteries 2019-2029. Available online: https:/ /www.idtechex.com/es/research-report/second-lifeelectric-vehicle-batteries-2019-2029/626 (accessed on 22 September 2021). 
15. Mubenga, N.S.; Sharma, K.; Stuart, T. A bilevel equalizer to boost the capacity of second life li ion batteries. Batteries $2019,5,55$. [CrossRef]

16. Zhang, X.-Q.; Cheng, X.-B.; Zhang, Q. Advances in interfaces between li metal anode and electrolyte. Adv. Mater. Interfaces 2018, 5, 1701097. [CrossRef]

17. Fan, X.; Chen, L.; Ji, X.; Deng, T.; Hou, S.; Chen, J.; Zheng, J.; Wang, F.; Jiang, J.; Xu, K.; et al. Highly fluorinated interphases enable high-voltage li-metal batteries. Chem 2018, 4, 174-185. [CrossRef]

18. Li, T.; Liu, H.; Shi, P.; Zhang, Q. Recent progress in carbon/lithium metal composite anode for safe lithium metal batteries. Rare Met. 2018, 37, 449-458. [CrossRef]

19. Somakettarin, N.; Funaki, T. Study on factors for accurate open circuit voltage characterizations in mn-type li-ion batteries. Batteries 2017, 3, 8. [CrossRef]

20. Liang, Y.; Zhao, C.; Yuan, H.; Chen, Y.; Zhang, W.; Huang, J.; Yu, D.; Liu, Y.; Titirici, M.; Chueh, Y.; et al. A review of rechargeable batteries for portable electronic devices. InfoMat 2019, 1, 6-32. [CrossRef]

21. Choi, N.-S.; Chen, Z.; Freunberger, S.A.; Ji, X.; Sun, Y.-K.; Amine, K.; Yushin, G.; Nazar, L.F.; Cho, J.; Bruce, P.G. Challenges facing lithium batteries and electrical double-layer capacitors. Angew. Chem. Int. Ed. 2012, 51, 9994-10024. [CrossRef] [PubMed]

22. Patil, A.; Patil, V.; Shin, D.W.; Choi, J.-W.; Paik, D.-S.; Yoon, S.-J. Issue and challenges facing rechargeable thin film lithium batteries. Mater. Res. Bull. 2008, 43, 1913-1942. [CrossRef]

23. Gröger, O.; Gasteiger, H.; Suchsland, J.-P. Review-Electromobility: Batteries or fuel cells? J. Electrochem. Soc. 2015, 162, A2605-A2622. [CrossRef]

24. Chaparro, A.M.; Ferreira-Aparicio, P.; Folgado-Martínez, M.A.; Conde, J.J.; de Rafael Valdivia, D.; Miguel Verdugo, F.J. HydrogenPowered Fuel Cell. Spanish Patent WO2020240063A1, 2020.

25. Wittstock, R.; Pehlken, A.; Wark, M. Challenges in Automotive Fuel Cells Recycling. Recycling 2016, 1, 343. [CrossRef]

26. Blake, B.E.; Fenton, S.E. Early life exposure to per- and polyfluoroalkyl substances (PFAS) and latent health outcomes: A review including the placenta as a target tissue and possible driver of peri- and postnatal effects. Toxicology 2020, 443, 152565. [CrossRef] [PubMed]

27. Stoiber, T.; Evans, S.; Naidenko, O.V. Disposal of products and materials containing per- and polyfluoroalkyl substances (PFAS): A cyclical problem. Chemosphere 2020, 260, 127659. [CrossRef] [PubMed]

28. EU Project. Fuel Cells and Hydrogen 2 Joint Undertaking Under Grant Agreement No 101007216. Sustainable Solutions for Recycling of End-Of-Life Hydrogen Technologies(Best4Hy Project). Available online: https://best4hy-project.eu/ (accessed on 11 October 2021).

29. Pehnt, M. Life-cycle analysis of fuel cell system components. Handb. Fuel Cells 2010, 94, 1293-1317. [CrossRef]

30. Valente, A.; Iribarren, D.; Dufour, J. Harmonising methodological choices in life cycle assessment of hydrogen: A focus on acidification and renewable hydrogen. Int. J. Hydrogen Energy 2019, 44, 19426-19433. [CrossRef]

31. Valente, A.; Iribarren, D.; Dufour, J. Cumulative energy demand of hydrogen energy systems. In Environmental Footprints and Eco-Design of Products and Processes; Gabler: Berlin/Heidelberg, Germany, 2018; pp. 47-75.

32. Valente, A.; Iribarren, D.; Dufour, J. Life cycle sustainability assessment of hydrogen from biomass gasification: A comparison with conventional hydrogen. Int. J. Hydrogen Energy 2019, 44, 21193-21203. [CrossRef]

33. Valente, A.; Iribarren, D.; Dufour, J. Validation of GreenH ${ }_{2}$ armony ${ }^{\circledR}$ as a tool for the computation of harmonised life-cycle indicators of hydrogen. Energies 2020, 13, 1603. [CrossRef]

34. Valente, A.; Iribarren, D.; Dufour, J. Harmonised carbon and energy footprints of fossil hydrogen. Int. J. Hydrogen Energy 2021, 46, 17587-17594. [CrossRef]

35. Valente, A.; Iribarren, D.; Dufour, J. Harmonised life-cycle global warming impact of renewable hydrogen. J. Clean. Prod. 2017, 149, 762-772. [CrossRef]

36. Valente, A.; Iribarren, D.; Dufour, J. Harmonised life-cycle indicators of nuclear-based hydrogen. Int. J. Hydrogen Energy 2020, 46, 29724-29731. [CrossRef]

37. Candelaresi, D.; Valente, A.; Iribarren, D.; Dufour, J.; Spazzafumo, G. Comparative life cycle assessment of hydrogen-fuelled passenger cars. Int. J. Hydrogen Energy 2021. [CrossRef]

38. Bargiacchi, E.; Candelaresi, D.; Valente, A.; Spazzafumo, G.; Frigo, S. Life cycle assessment of substitute natural gas production from biomass and electrolytic hydrogen. Int. J. Hydrogen Energy 2021. [CrossRef]

39. Wulf, C.; Kaltschmitt, M. Life cycle assessment of hydrogen supply chain with special attention on hydrogen refuelling stations. Int. J. Hydrogen Energy 2012, 37, 16711-16721. [CrossRef]

40. Ally, J.; Pryor, T. Life-cycle assessment of diesel, natural gas and hydrogen fuel cell bus transportation systems. J. Power Sources 2007, 170, 401-411. [CrossRef]

41. Bicer, Y.; Dincer, I. Life cycle evaluation of hydrogen and other potential fuels for aircrafts. Int. J. Hydrogen Energy 2017, 42, 10722-10738. [CrossRef]

42. Mori, M.; Stropnik, R.; Sekavčnik, M.; Lotrič, A. Criticality and life-cycle assessment of materials used in fuel-cell and hydrogen technologies. Sustainability 2021, 13, 3565. [CrossRef]

43. Garraín, D.; Lechón, Y. Exploratory environmental impact assessment of the manufacturing and disposal stages of a new PEM fuel cell. Int. J. Hydrogen Energy 2014, 39, 1769-1774. [CrossRef] 
44. Usai, L.; Hung, C.R.; Vásquez, F.; Windsheimer, M.; Burheim, O.S.; Strømman, A.H. Life cycle assessment of fuel cell systems for light duty vehicles, current state-of-the-art and future impacts. J. Clean. Prod. 2021, 280, 125086. [CrossRef]

45. Cox, B.; Bauer, C.; Beltran, A.M.; van Vuuren, D.P.; Mutel, C.L. Life cycle environmental and cost comparison of current and future passenger cars under different energy scenarios. Appl. Energy 2020, 269, 115021. [CrossRef]

46. Chen, Y.; Hu, X.; Liu, J. Life cycle assessment of fuel cell vehicles considering the detailed vehicle components: Comparison and scenario analysis in China based on different hydrogen production schemes. Energies 2019, 12, 3031. [CrossRef]

47. Sharma, S.; Ghoshal, S.K. Hydrogen the future transportation fuel: From production to applications. Renew. Sustain. Energy Rev. 2015, 43, 1151-1158. [CrossRef]

48. Cantuarias-Villessuzanne, C.; Weinberger, B.; Roses, L.; Vignes, A.; Brignon, J.-M. Social cost-benefit analysis of hydrogen mobility in Europe. Int. J. Hydrogen Energy 2016, 41, 19304-19311. [CrossRef]

49. Sharma, A.; Strezov, V. Life cycle environmental and economic impact assessment of alternative transport fuels and power-train technologies. Energy 2017, 133, 1132-1141. [CrossRef]

50. Mehmeti, A.; McPhail, S.J.; Pumiglia, D.; Carlini, M. Life cycle sustainability of solid oxide fuel cells: From methodological aspects to system implications. J. Power Sources 2016, 325, 772-785. [CrossRef]

51. Cai, J.; Gervasio, D.F. The nature of surface oxides on corrosion-resistant nickel alloy covered by alkaline water. Nanoscale Res. Lett. 2010, 5, 613-619. [CrossRef] [PubMed]

52. Ben Jadi, S.; El Jaouhari, A.; Aouzal, Z.; El Guerraf, A.; Bouabdallaoui, M.; Wang, R.; Bazzaoui, E.; Bazzaoui, M. Electropolymerization and corrosion resistance of polypyrrole on nickel bipolar plate for PEM fuel cell application. Mater. Today Proc. 2020, 22, 52-56. [CrossRef]

53. ISO, International Standard Organization. Environmental Management_Life Cycle Assessment_Principles and Framework; ISO 14040:2006; ISO: Geneva, Switzerland, 2006.

54. ISO, International Standard Organization. Environmental Management_Life Cycle Assessment_Requirements and Guidelines; ISO 14044:2006; ISO: Geneva, Switzerland, 2006.

55. European Union. European commission recommendation 2013/179/EU on the use of common methods to measure and communicate the life cycle environmental performance of products and organisations. Off. J. Eur. Union 2013, 210.

56. Wolf, M.-A.; Pant, R.; Chomkhamsri, K.; Sala, S.; Pennington, D. The International Reference Life Cycle Data System (ILCD) Handbook; European Commission, Ed.; EC—Joint Research Center-IES: Ispra, Italy, 2012; ISBN 978-927-921-640-4.

57. Leontief, W.W. Quantitative input and output relations in the economic systems of the United States. Rev. Econ. Stat. 1936, 18, 105. [CrossRef]

58. Miller, R.E.; Blair, P.D. Input-Output Analysis: Foundations and Extensions; Cambridge University Press: Cambridge, UK, 2009.

59. Yamano, N.; Ahmad, N. The OECD Input-Output Database: 2006 Edition; STI Working Paper; OECD: Paris, France, 2006.

60. OECD. OECD Inter-Country Input-Output (ICIO) Tables; OECD: Paris, France; Available online: https://www.oecd.org/sti/ind/ inter-country-input-output-tables.htm (accessed on 11 October 2021).

61. Wiebe, K.; Yamano, N. Estimating $\mathrm{CO}_{2}$ Emissions Embodied in Final Demand and Trade Using the OECD ICIO 2015: Methodology and Results; OECD Science, Technology and Industry: Paris, France, 2016.

62. Caldés, N.; Varela, M.; Santamaría, M.; Sáez, R. Economic impact of solar thermal electricity deployment in Spain. Energy Policy 2009, 37, 1628-1636. [CrossRef]

63. Banacloche, S.; Cadarso, M.A.; Monsalve, F.; Lechon, Y. Assessment of the sustainability of Mexico green investments in the road to Paris. Energy Policy 2020, 141, 111458. [CrossRef]

64. Banacloche, S.; Cadarso, M.Á.; Monsalve, F. Implications of measuring value added in exports with a regional input-output table. A case of study in South America. Struct. Chang. Econ. Dyn. 2020, 52, 130-140. [CrossRef] 